\title{
Evaluation and Management of Patients with Seizures in the Emergency Department: A One-Year Analysis
}

\author{
K. Puteikis* \\ K. Zdanytė** \\ R. Mameniškiené ${ }^{* * *}$ \\ *Vilnius University, \\ Faculty of Medicine, Lithuania \\ **University Hospital Muenster, \\ Muenster, Germany \\ *** Vilnius University, Faculty \\ of Medicine, Institute of Clinical \\ Medicine, Center of Neurology; \\ Vilnius University Hospital \\ Santaros Klinikos, Vilnius
}

\begin{abstract}
Summary. Introduction. Transient loss of consciousness (TLoC) encompasses symptoms caused by either syncope, seizures or psycogenic disorders which are all frequent in the emergency department (ED). The study aims to determine the prevalences of causes of TLoC in the $\mathrm{ED}$, analyse the characteristics of patients with seizures or established epilepsy in particular and estimate the level of evaluation and management they receive in respect to available international guidelines.

Materials and methods. The data was cross-sectional and was retrieved from the local database of Vilnius University Hospital Santaros Klinikos from January $1^{\text {st }}$ to December $31^{\text {st }}$, 2016. Adult patients with diagnoses (coded in the International Statistical Classification of Diseases and Related Health Problems, ICD-10-AM) of syncope (R55), epilepsy (G40) or other and unspecified convulsions (R56.8) assigned either by the emergency medical services or the ED staff were involved in the study (315 cases). The data was analysed with Microsoft Excel v16.0 and IBM SPSS Statistics v20, two-sided Fisher's exact and MannWhitney U tests were employed ( $\mathrm{p}<0.05)$.

Results. As diagnoses provided by emergency services and the ED staff were conflicting, only the latter were used for the assortment. The majority of patients brought to the ED with TLoC (average age 53.5 \pm 20.8 ) had syncope or collapse (134, 42.5\%), $54(17.1 \%)$ had epilepsy, and $32(10.2 \%)$ had other and unspecified convulsions, which encompass mostly new-onset seizures. The mean age of patients with established epilepsy was $47.6 \pm 15.7$ and significantly $(\mathrm{p}=0.014)$ lower than due to other causes. Male gender predominated in allcause seizures (odds ratio $\mathrm{OR}=1.7 ; 95 \%$ confidence interval $\mathrm{CI}=1.0-2.9, \mathrm{p}=0.042$ ). Laboratory blood tests were commonly used for all patients, but patients with epilepsy received computed tomography (CT) scans and were hospitalized more often than other patients $(\mathrm{p}<0.001, \mathrm{p}=0.002$, respectively). Both an electrocardiography (ECG) and troponin blood levels (both often received after syncope and collapse) were evaluated less frequently in these cases, however $(\mathrm{p}<0.001)$. Focal seizures $(32,59.3 \%)$ and alcohol-related metabolic seizures $(8,14.8 \%)$ were most common with epilepsy; unknown or unspecified $(22,68.8 \%)$ and generalized $(6,18.8 \%)$ - with new-onset seizures. For outpatients with epilepsy, alcohol abstinence $(16,44.4 \%)$ and everyday (lifestyle, work etc.) recommendations $(13,36.1 \%)$ were most common, treatment was often modified $(14,38.9 \%)$. Outpatients with seizures but no diagnosed epilepsy were most often advised to consult a neurologist, receive an electroencephalography (EEG) $(19,76.0 \%$ and $11,44.0 \%$, respectively), and abstain from alcohol $(11,44.0 \%)$, but treatment was almost never prescribed.

Conclusions. Syncope and collapse caused most cases of TLoC, followed by established epilepsy and new-onset seizures. Patients with epilepsy were younger than in other cases and in assessing all presentations with seizures, male gender predominated. The evaluative practices and care complied with selected international guidelines in most cases, except for some approaches related to neuroimaging and information deliverance.
\end{abstract}

Keywords: transient loss of consciousness, epilepsy, seizures, emergency department.

\footnotetext{
Address:

Kristijonas Puteikis

Vilnius University, Faculty of Medicine

M. K. Čiurlionio st. 21, LT-03101 Vilnius

Email: kristijonas.puteikis@mf.stud.vu.lt
}

\footnotetext{
(C) Neurologijos seminarai, 2018. Open Access. This article is distributed under the terms of the Creative Commons Attribution 4.0 International License CC-BY 4.0 (http://creativecommons.org/licenses/by/4.0/), which permits unrestricted use, distribution, and reproduction in any medium, provided you give appropriate credit to the original author(s) and the source, provide a link to the Creative Commons license, and indicate if changes were made.
} 


\section{INTRODUCTION}

Epilepsy, with a prevalence of 8.3 per 1000 inhabitants in 2016 in Lithuania, is a common and costly neurological disorder with epileptic seizures presumed to cause about $1-2 \%$ of all emergency department (ED) visits [1-3]. Together with situational or cardiogenic syncope and panic attacks, seizures and epilepsy cause the vast majority of occurrences when patients with transient loss of consciousness (TLoC) are brought to the ED [4]. Guidelines available for clinicians for managing seizures altogether are not always easily implemented in practice due to their tendency to generalize some aspects of care for patients presenting with heterogeneous symptoms and different options of their management [5, 6]. However, The American College of Emergency Physicians (ACEP) shares clinical policy for investigating seizures specifically in the ED, the National Institute for Health and Care Excellence (NICE) and The Scottish Intercollegiate Guidelines Network (SIGN) have published general guidelines for epilepsy care, the latter being recent and well evaluated in earlier versions by the International League Against Epilepsy (ILAE) [5-10]. In addition, The American Academy of Neurology and the American Epilepsy Society (AAN and AES) present recommendations for dealing with a first unprovoked seizure [11]. Such guidelines indicate in which circumstances patients with seizures should receive general advice, laboratory testing, have neuroimaging or an electroencephalography (EEG) performed, begin treatment with anti-epileptic drugs (AEDs) or be hospitalized. As the data from various studies is summarized in these guidelines and is graded by levels of scientific evidence by ACEP, SIGN, AAN and AES from A to C by ACEP, SIGN, AAN and AES (A being from class I-II studies, B from class II-III and $\mathrm{C}$ from low to middle strength class III studies) and according to classes I-III by NICE, the recommendations become a useful means to estimate the quality of evaluation and care that patients presenting seizures receive in a particular ED. To our knowledge, studies aiming to perform a similar task are not very frequent, especially when considering the fact that the National Audit of Seizure management in Hospitals (NASH) study of 2015 in the United Kingdom claims to probably be the first of its kind worldwide [3].

\section{OBJECTIVES}

The main aims of the study were to determine the prevalence of epilepsy and seizures in comparison to other causes of TLoC in our local ED, investigate the main characteristics of patients presenting with TLoC and seizures specifically, and evaluate the care and indications received by patients having seizures or diagnosed with epilepsy in the context of existing international guidelines.

\section{MATERIALS AND METHODS}

The study was conducted in the ED of Vilnius University Hospital Santaros Klinikos by analyzing cross-sectional data from January $1^{\text {st }}$ to December $31^{\text {st }}, 2016$. The data was collected on patients with one of the selected disease codes assigned to them: R55 (syncope and collapse), R56.8 (other and unspecified convulsions, used for newonset seizures) or G40 (epilepsy, any subcode), according to the International Statistical Classification of Diseases and Related Health Problems, Tenth Revision, Australian Modification (ICD-10-AM). The selected patients were either brought to the ED having one of the codes as a primary diagnosis or symptom (provided by emergency medical services) or were assigned these codes as their final diagnosis in the ED after evaluation. All patients were adults ( $\geq 18$ years old). The computerized hospital database was used to extract the medical history, chief complaints, the results of basic physical and neurological examinations (if performed) and information, and whether other tests (laboratory, neuroimaging, EEG, electrocardiography) were executed. Recommendations for patients and their treatment options were determined from the database as well. There was a total of 315 cases of patients from 18 to 96 years old that fulfilled our criteria. The investigation was retrospective in nature partly for simplicity, to require less labor, and partly due to the fact that no follow up information about most patients could be collected as they normally received outpatient services of primary and secondary care in other clinics of our town.

\section{Statistical Analysis}

The data was analyzed with Microsoft Excel (Version 16.0, Microsoft Corp., Redmond, WA, USA) and the IBM SPSS Statistics (Version 20.0, IBM Corp., Armonk, NY, USA). The sample size was not large, therefore Fisher's exact test was performed to determine the association between variables. Normality for age distribution was tested with Kolmogorov-Smirnov and ShapiroWilk tests. Mann-Whitney U test was applied to compare mean age between selected groups as age distribution was symmetrical but not normal in most cases (except for patients with a diagnosis of epilepsy) and differed in variances, therefore, assumptions for a Student's t-test did not hold. All tests were two-sided and the level of significance was set to $\mathrm{p}<0.05$.

\section{RESULTS}

Basic patient characteristics and the rates of most common causes of TLoC are presented in Table 1. Primary diagnoses received from emergency medical services remained the same as the final diagnoses in the ED in only $93(29.5 \%)$ of 315 cases. A primary diagnosis of epilepsy (G40) occurred 36 (11.4\%) times and matched a final 
Table 1. Patient age groups and the most frequent final diagnoses according to the ICD-10-AM

\begin{tabular}{|c|c|c|c|c|c|c|c|}
\hline \multirow{2}{*}{ Age group } & \multirow{2}{*}{ Number of cases } & \multirow{2}{*}{$\begin{array}{l}\text { Average } \\
\text { age (SD) }\end{array}$} & \multicolumn{5}{|c|}{ Final diagnosis } \\
\hline & & & G40 & R55 & R56.8 & I60-I69 & I00-I99 \\
\hline$<20$ & 13 & $18.5(0.52)$ & 2 & 7 & 1 & & \\
\hline $20-29$ & 42 & $24.1(2.50)$ & 5 & 23 & 7 & & \\
\hline $30-39$ & 36 & $34.4(2.92)$ & 7 & 14 & 6 & & \\
\hline $40-49$ & 44 & $44.7(3.12)$ & 19 & 10 & 2 & & 2 \\
\hline $50-59$ & 57 & $54.9(2.62)$ & 11 & 26 & 5 & 1 & 3 \\
\hline $60-69$ & 34 & $65.4(2.51)$ & 5 & 16 & 3 & 1 & 7 \\
\hline $70-79$ & 49 & $74.6(2.74)$ & 5 & 21 & 3 & 4 & 13 \\
\hline $80-89$ & 37 & $83.7(3.13)$ & 0 & 15 & 5 & 4 & 11 \\
\hline$\geq 90$ & 3 & $92.3(3.21)$ & 0 & 2 & & 0 & 1 \\
\hline Total (\% of total cases) & 315 & $53.5(20.8)$ & $54(17.1 \%)$ & $134(42.5 \%)$ & $32(10.2 \%)$ & $10(3.2 \%)$ & $37(11.8 \%)$ \\
\hline $\begin{array}{l}\text { Males ( } \% \text { in groups of one } \\
\text { diagnosis) }\end{array}$ & $166(52.7 \%$ of total $)$ & $50.0(21.9)$ & $35(64.8 \%)$ & $61(45.5 \%)$ & $25(78.1 \%)$ & $4(40.0 \%)$ & $17(45.9 \%)$ \\
\hline $\begin{array}{l}\text { Females ( } \% \text { in groups of } \\
\text { one diagnosis) }\end{array}$ & $149(47.3 \%$ of total $)$ & $54.9(22.4)$ & $19(35.2 \%)$ & $73(55.5 \%)$ & $7(21.9 \%)$ & $6(60.0 \%)$ & $20(54.1 \%)$ \\
\hline
\end{tabular}

G40 - epilepsy, R55 - syncope and collapse, R56.8 - other and unspecified convulsions, I00-I99 - diseases of the circulatory system (I60-I69 of which - cerebrovascular diseases).

diagnosis of epilepsy in $22(61.1 \%)$ of these cases (in only 3 such cases, the primary and final diagnosis had identical subcodes). In the rest of patients with a final ED diagnosis of epilepsy, $14(25.9 \%)$ of the total 54 had a primary diagnosis of other and unspecified convulsions (R56.8). Due to such inconsistencies between primary and final diagnostic codes, only the latter were used as criteria when conducting a further analysis.

The average age of patients presenting with established epilepsy was $47.6 \pm 15.7$, and it was significantly lower (Mann-Whitney $\mathrm{U}=5551, \mathrm{p}=0.014$ ) in comparison to the age of patients diagnosed with other disorders (54.7 \pm 21.5$)$. Age distribution was normal for the epilepsy group and peaked at about middle-age (around 40-49 years). Patient gender was not associated with being assigned a final diagnosis of epilepsy $(p=0.053)$. Data concerning the most common clinical tests received by patients diagnosed with epilepsy in contrast to those presenting with an alternative cause of TLoC is summarized in Table 2. In addition, one pregnancy test and one lumbar puncture were performed. Patients with TLoC were hospitalized in the neurology department more often than any other department (28 $(50.9 \%)$ of 55 instances). In cases of epilepsy diagno- sis, the latter was associated with hospitalization (including a recommendation to be hospitalized) both in the general and in the neurology department (18 (33.3\%) of 54 patients with epilepsy hospitalized, of them $16(29.6 \%)$ in the neurology department, $\mathrm{p}=0.002$ and $\mathrm{p}<0.001$, respectively). Among the diagnoses of epilepsy, the most common were G40.20 and G40.21 (defined as "localization-related (focal) (partial) symptomatic epilepsy and epileptic syndromes with complex partial seizures", either not intractable or intractable, respectively), which amounted to $29(53.7 \%)$ cases. $15(27.8 \%)$ patients presented to the ED were with a positive history of alcohol use, 8 (14.8\%) with epileptic seizures related to external causes (alcohol use in our investigation). For $15(27.8 \%)$ patients with the diagnosis of epilepsy it was the first occurrence of seizures in their lives, according to their medical history (5 (33.3\%) structural, 6 (40.0\%) metabolic and 4 (26.7\%) unspecified cases).

It is noteworthy that some patients with new-onset seizures could not be determined to have epilepsy and were rather diagnosed with "other and unspecified convulsions" (R56.8). Data for the comparison of seizure types, received recommendations and tests between cases of epilepsy and

Table 2. Rates of frequent tests performed in the ED in both the instance of epilepsy and an alternative disorder

\begin{tabular}{||l|c|c|c||}
\hline \multirow{2}{*}{ Type of test } & \multicolumn{2}{|c|}{ Number of tests performed (percentage of patients in separate groups) } & \multirow{2}{*}{ Significance } \\
\cline { 2 - 3 } & Patients with diagnosis of epilepsy & Patients with other diagnoses & \\
\hline Complete blood count (CBC) & $44(81.5 \%)$ & $231(89.5 \%)$ & $\mathrm{p}=0.107$ \\
\hline Blood glucose & $42(77.8 \%)$ & $218(84.5 \%)$ & $\mathrm{p}=0.232$ \\
\hline Electrolytes & $44(81.5 \%)$ & $233(89.6 \%)$ & $\mathrm{p}=0.105$ \\
\hline Biochemical tests & $45(83.3 \%)$ & $235(90.4 \%)$ & $\mathrm{p}=0.148$ \\
\hline ECG (with QT) & $5(9.3 \%)$ & $130(50.4 \%)$ & $\mathbf{p}<\mathbf{0 . 0 0 1}$ \\
\hline Troponin level & $7(13.0 \%)$ & $129(49.6 \%)$ & $\mathbf{p}<\mathbf{0 . 0 0 1}$ \\
\hline Computed tomography (CT) & $44(81.5 \%)$ & $114(45.4 \%)$ & $\mathbf{p}<\mathbf{0 . 0 0 1}$ \\
\hline
\end{tabular}


Evaluation and Management of Patients with Seizures in the Emergency Department: A One-Year Analysis

Table 3. Seizure characteristics, frequent clinical tests and recommendations concerning all patients with seizures

\begin{tabular}{|c|c|c|c|}
\hline Code of diagnosis & G40 & R56.8 & Significance level \\
\hline Males & $35(64.8 \%)$ & $25(78.1 \%)$ & $\mathrm{p}=0.231$ \\
\hline \multicolumn{4}{|c|}{ Seizure types or etiology } \\
\hline Focal & $32(59.3 \%)$ & $0(0 \%)$ & $\mathbf{p}<\mathbf{0 . 0 0 1}$ \\
\hline Generalized & $7(13.0 \%)$ & $6(18.8 \%)$ & $\mathrm{p}=0.540$ \\
\hline Metabolic/provoked & $8(14.8 \%)$ & $4(12.5 \%)$ & $\mathrm{p}=1.000$ \\
\hline Unknown or unspecified & $7(13.0 \%)$ & $22(68.8 \%)$ & $\mathrm{p}<0.001$ \\
\hline Total & 54 & 32 & \\
\hline \multicolumn{4}{|c|}{ Special tests performed and hospitalization } \\
\hline Computed tomography (CT) & $44(81.5 \%)$ & $30(93.8 \%)$ & $\mathrm{p}=0.196$ \\
\hline EEG (in the neurology department when hospitalized) & $14(25.9 \%)$ & $9(28.1 \%)$ & $\mathrm{p}=1.000$ \\
\hline Electrocardiography (ECG) & $5(9.3 \%)$ & $16(50.0 \%)$ & $\mathrm{p}<0.001$ \\
\hline Troponin levels & $7(13.0 \%)$ & $4(12.5 \%)$ & $\mathrm{p}=1.000$ \\
\hline Hospitalization & $18(33.3 \%)$ & $7(21.9 \%)$ & $\mathrm{p}=0.329$ \\
\hline \multicolumn{4}{|c|}{ Recommendations for outpatient care } \\
\hline Consult a neurologist/epileptologist & $9(25.0 \%)$ & $19(76.0 \%)$ & $\mathrm{p}<\mathbf{0 . 0 0 1}$ \\
\hline Obtain an EEG in an outpatient clinic & $6(16.6 \%)$ & $11(44.0 \%)$ & $\mathrm{p}=\mathbf{0 . 0 2 4}$ \\
\hline Abstinence from alcohol & $16(44.4 \%)$ & $11(44.0 \%)$ & $\mathrm{p}=1.000$ \\
\hline Write a seizure diary & $4(11.1 \%)$ & $1(4.0 \%)$ & $\mathrm{p}=0.640$ \\
\hline Preventative measures explained & $13(36.1 \%)$ & $7(28.0 \%)$ & $\mathrm{p}=0.586$ \\
\hline Indications for AED treatment present & $25(69.4 \%)$ & $2(8.0 \%)$ & $\mathrm{p}<\mathbf{0 . 0 0 1}$ \\
\hline Treatment with AED started or modified & $14(38.9 \%)$ & $2(8.0 \%)$ & $\mathrm{p}=\mathbf{0 . 0 0 8}$ \\
\hline Total outpatient ( $\%$ of all cases in the group) & $35(64.8 \%)$ & $25(78.1 \%)$ & \\
\hline
\end{tabular}

G40 - epilepsy, R56.8 - other and unspecified convulsions, EEG - electroencephalography, AED - anti-epileptic drugs.

those of other seizure activity is presented in Table 3 . The average age of patients presenting with seizures, but not epilepsy was $49.8 \pm 22.3$ and was not significantly different from the average age of epilepsy patients (Mann-Whitney $\mathrm{U}=828, \mathrm{p}=0.748)$. Male gender was associated with newonset seizures $(\mathrm{p}=0.003)$ and also when any seizure activity (R56.8 or G40) was considered (odds ratio $\mathrm{OR}=1.7$; $95 \%$ confidence interval $\mathrm{CI}=1.0-2.9, \mathrm{p}=0.042)$. Of all patients with the diagnosis code of R56.8, 27 (84.4\%) received a complete blood count, glucose and electrolyte blood tests, $28(87.5 \%)$ had an additional biochemical test performed. Considering further explanation on the diagnosis (when specified), for $19(59.4 \%)$ of the 32 patients the cause of TLoC was the first seizure in their lives, according to their medical history (but only 7 (21.9\%) had such a comment with the diagnosis), 9 (28.1\%) said to have had a similar episode before, but then epilepsy was not diagnosed, $4(12.5 \%$ ) had a provoked seizure (3 due to alcohol use, 1 due to a structural insult). Alcohol use was positive in $7(21.9 \%)$ cases out of $10(31.3 \%)$, when the inquiry was mentioned in the medical history.

\section{DISCUSSION}

Transient loss of consciousness has been introduced as an umbrella term to define manifestations of syncope, epileptic seizures, pseudoseizures and some similar events [4,
12]. Syncope and collapse are noted to occur more often than epileptic seizures in ED admissions, which was a finding in our study as well $[12,13]$. Our analysis lacked statistical power to show association between male gender and diagnosed epilepsy, but the relation was found when all occurrences of seizure activity were considered and therefore correlated with findings from other studies [2, 14, 15]. As only adults ( $\geq 18$ years) were involved in our study, no bimodal distribution of age was found with a peak during childhood, but the peak age for epilepsy patients visiting the ED matched findings from a large study in United States, being around the middle age (patients about 40-49 years old) [2, 15].

Discussion of patient evaluation and management in the ED becomes difficult due to the fact that ACEP policy and AAN/AES guidelines refer to patients with new-onset seizures, which is strenuous to analyze as patients are often uncooperative, their full medical history is unknown or the caring physician does not provide information whether the seizure was not previously experienced $[7,8,11]$. However, the recommendations often correlate well with guidelines (from NICE or SIGN, for example) for seizure management in general and patients assigned code of R56.8 fit in the notion of new-onset seizures by not being diagnosed with epilepsy at the moment of admission to the ED, even though they sometimes report seizure-like events for which they either gave no special attention or their caring physician lacked objective evi- 
dence to diagnose epilepsy. Therefore, guidelines by ACEP and AAN/AES are consequently left in the discussion.

\section{Laboratory tests}

ACEP grades laboratory tests for glucose and sodium levels as a level B recommendation, encourages to obtain a pregnancy test for women of childbearing age and a lumbar puncture for immunocompromised patients [7]. In our study, the vast majority of all patients received a complete blood count and tests for glucose and electrolyte levels (according to the ED protocol) together with additional biochemical tests. Such basic testing for patients with seizures is endorsed by NICE [9]. In cases of an established diagnosis of epilepsy, ECG testing was less frequent for the reason that the most frequent cause of TLoC was syncope or yet unrecognized seizure activity, when a 12-lead ECG is advised [4]. Only one patient with an anxiety disorder was tested for pregnancy, however the number of women with new-onset seizures was low as well. The single lumbar puncture recorded was for a patient with a urinary tract infection, and no immunocompromised patients with seizures were brought in.

\section{Neuroimaging tests}

As information about magnetic resonance imaging (MRI) is not incorporated into the hospital database and the test is known to be much less frequent, only CT scans were evaluated. Patients with epilepsy received CT scans more frequently than in other circumstances but not more than in the case of unspecified seizure activity. This finding correlates well with the ACEP protocol (level B) which emphasizes the need for neuroimaging tests when a follow-up is not guaranteed (which was the case) [7]. However, MRI should be a priority when available, according to NICE (class III) and SIGN (grades C and D), while CT should remain a second option (as are the circumstances in the ED of our study) $[9,10]$.

\section{Electroencephalography (EEG) and further consulting}

About a quarter of patients received an EEG as they were hospitalized irrespectively of whether or not they had been presented with new-onset seizures or epilepsy. Recommendations for employing EEG are somewhat scarce and its use should depend on the individual case in question as an optional choice for the professional neurologist, according to SIGN (class III) and ACEP (grade C) [7, 10]. NICE does not encourage interictal EEG use when the diagnosis is already established (class III) - the recommendation for such patients occurred less often in our findings in comparison to events with new-onset seizures [9]. The same applied for guiding a patient to consult a neurologist as an outpatient.

\section{Treatment with anti-epileptic drugs (AEDs)}

According to the AAN and AES, prescription of AEDs after a first seizure has not been shown to increase the chance of long-term seizure remission ( $>3$ years) or improve patients' quality of life (level B and C of evidence, respectively) [11]. ACEP (level C), SIGN (level B) and NICE (class IIb) do not encourage AED use after a first seizure when no structural abnormality, other neurological problems, and unequivocal EEG discharges are present and the patient does not consider a new seizure unacceptable [7-10]. In our study, only 2 patients who had no diagnosis of epilepsy (and were later discharged from the ED) received advice on treatment: one was using carbamazepine, had an alcohol-provoked seizure and was advised to discontinue the drug due to a rash, the other was recommended to take clonazepam for 7-10 days. Therefore, the data represents good correlation with the consensus to delay AED therapy until a second seizure occurs. Both SIGN and NICE recommend an individual approach when treatment ought to be modified for patients with an established diagnosis and a revision of AED in use after seizure events: our findings represented a similar approach as in some occasions treatment was modified or initiated (after relapse, for example), however indications were not present at all for almost one third of cases. Both SIGN and NICE discourage routine tests for blood AED levels, a practice that was not considered in our study $[9,10]$.

\section{Preventative measures}

Prevention of injury and death and a thorough understanding of seizures or epilepsy by the patient are crucial for long-term care, therefore NICE, SIGN and the AAN/AES encourage presenting information to patients [9-11]. Measures concerning work, lifestyle, driving, seizure triggers were mentioned in about one third of seizure-related cases, but information about seizure recurrence risks (level A recommendation by the AAN/AES) was either not presented or not properly reported in the database. A similar situation was observed when the patient was supposedly told about social, psychological needs and sources of seizure-related information. The conclusion is that a further analysis is required to determine the level of the informative actions that are undertaken in the ED investigated. Seizure diaries have been proposed for some patients, although NICE noted a lack of data to either prove or disprove their usefulness [9]. Alcohol-related presentations and alcohol abuse were linked to a moderate part of events with seizures, similar to findings in other studies, where it was cited as a common cause or finding in such patients $[2,16,17]$. The urge not to consume alcohol was indicated more often than almost any other advice. During the analysis, it was noted that expressions used by physicians in such context were often rigorous (for example, "strict abstinence is compulsory", "total abstinence", "alcohol use is prohibited" with or without exclamation marks). On the other hand, the parts of the medical history concerning alcohol use have been found in 
only about one third of seizure events (both new-onset and with epilepsy). The alcohol use disorders identification test (AUDIT) might supplement the examination (especially in cases of alcohol-related seizures), but lack of respective protocol indications in the ED and time constraints probably make such a task problematic [18].

\section{STUDY LIMITATIONS}

Some of the limitations of the study are inclusion criteria, based strictly on coded diagnoses, a short period of study, and, consequently, a small sample size. Data was acquired from one emergency department and therefore no conclusions could be drawn concerning seizure evaluation and care on a multicenter or national level. The analysis relied on the data provided to the database by physicians, which was sometimes not detailed or commented. No follow-up evaluations on patient compliance were considered in the study, this being one of the major drawbacks.

\section{CONCLUSIONS}

Our study shows that syncope and collapse is more common among cases of TLoC than seizures of any cause. ED visits in adults with epilepsy peak during middle age and all-cause seizures are more associated with male gender, consistent with findings in other studies. In most aspects, the practice of the investigated ED complied with selected protocols by ACEP and guidelines by NICE, SIGN, AAN and AES. A need for more attention to MRI availability, recommendations (and their registering in the database) for patients concerning social, psychological issues, directions for help and knowledge could be addressed, as well as place for improvement in alcohol abuse registering. However, more investigation ought to be conducted to review the characteristics of information received by the patients with seizures and established epilepsy. Prospective studies are required to estimate patient compliance with the recommendations they receive in the ED or to evaluate the benefits of different evaluation and management strategies of patients presenting with seizures to the ED.

\section{References}

1. Gaidelytė R, Garbuvienė M. Health Statistics of Lithuania 2016. Health Information Centre of Institute of Hygiene, 2017.

2. Martindale JL, Goldstein JN, Pallin DJ. Emergency department seizure epidemiology. Emergency Medicine Clinics 2011; 29(1): 15-27. https://doi.org/10.1016/j.emc.2010.08. 002

3. Dixon PA, Kirkham JJ, Marson AG, Pearson MG. National Audit of Seizure management in Hospitals (NASH): results of the national audit of adult epilepsy in the UK. BMJ Open 2015; 5(3): e007325. https://doi.org/10.1136/bmjopen2014-007325
4. Rogers G, O’Flynn N. NICE guideline: transient loss of consciousness (blackouts) in adults and young people. The British Journal of General Practice 2011; 61(582): 40-2. https://doi.org/10.3399/bjgp11X548965

5. Sauro KM, Wiebe S, Dunkley C, et al. The current state of epilepsy guidelines: a systematic review. Epilepsia 2016; 57(1): 13-23. https://doi.org/10.1111/epi.13273

6. Dunkley C, Cross JH. NICE guidelines and the epilepsies: how should practice change? Archives of Disease in Childhood 2006; 91(6): 525-8. https://doi.org/10.1136/adc.2005. 080036

7. ACEP Clinical Policies Committee. Clinical policy: Critical issues in the evaluation and management of adult patients presenting to the emergency department with seizures. Annals of Emergency Medicine 2004; 43(5): 605. https://doi.org/10.1016/j.annemergmed.2004.01.017

8. Huff JS, Melnick ER, Tomaszewski CA, et al. Clinical policy: critical issues in the evaluation and management of adult patients presenting to the emergency department with seizures. Annals of Emergency Medicine 2014; 63(4): 437-47. https://doi.org/10.1016/j.annemergmed.2014.01.018

9. National Clinical Guideline Centre (UK). The epilepsies: the diagnosis and management of the epilepsies in adults and children in primary and secondary care: pharmacological update of Clinical Guideline 20. NICE Clinical Guidelines No. 137, 2012.

10. Scottish Intercollegiate Guidelines Network (SIGN). Diagnosis and management of epilepsy in adults. SIGN publication No. 143, 2015.

11. Krumholz A, Wiebe S, Gronseth GS, et al. Evidence-based guideline: management of an unprovoked first seizure in adults: report of the Guideline Development Subcommittee of the American Academy of Neurology and the American Epilepsy Society. Neurology 2015; 84(16): 1705-13. https://doi.org/10.1212/WNL.0000000000001487

12. Van Dijk JG, Thijs RD, Benditt DG, Wieling W. A guide to disorders causing transient loss of consciousness: focus on syncope. Nature Reviews Neurology 2009; 5(8): 438-48. https://doi.org/10.1038/nrneurol.2009.99

13. Day SC, Cook EF, Funkenstein H, Goldman L. Evaluation and outcome of emergency room patients with transient loss of consciousness. The American Journal of Medicine 1982; 73(1): 15-23. https://doi.org/10.1016/0002-9343(82)90913-5

14. Huff JS, Morris DL, Kothari RU, Gibbs MA. Emergency department management of patients with seizures: a multicenter study. Academic Emergency Medicine 2001; 8(6): 622-8. https://doi.org/10.1111/j.1553-2712.2001.tb00175.x

15. Pallin DJ, Goldstein JN, Moussally JS, et al. Seizure visits in US emergency departments: epidemiology and potential disparities in care. International Journal of Emergency Medicine 2008; 1(2): 97-105. https://doi.org/10.1007/s12245008-0024-4

16. Krumholz A, Grufferman S, Orr ST, Stern BJ. Seizures and seizure care in an emergency department. Epilepsia 1989; 30(2): 175-81. https://doi.org/10.1111/j.1528-1157.1989. tb05451.x

17. Martikainen K, Seppä K, Viita P, et al. Transient loss of consciousness as reason for admission to primary health care emergency room. Scandinavian Journal of Primary Health Care 2003; 21(1): 61-4. https://doi.org/10.1080/ 02834310000591

18. Babor TF, Higgins-Biddle JC, Saunders JB, et al. AUDIT: The alcohol use disorders identification test: Guidelines for use in primary health care. World Health Organization, 2001. 


\section{K. Puteikis, K. Zdanytė, R. Mameniškienė}

\section{PACIENTU SU EPILEPSIJOS PRIEPUOLIAIS IVERTINIMAS IR KONSULTAVIMAS PRIËMIMO- SKUBIOSIOS PAGALBOS SKYRIUJE: VIENERIŲ METU ANALIZE்}

\section{Santrauka}

İvadas. Laikinas sąmonės netekimas būna sukeltas apalpimo, epilepsijos priepuoliu, diagnozuotos epilepsijos arba psichogeninių sutrikimų, kurie dažnai pasitaiko priėmimo-skubiosios pagalbos skyriuje. Šis tyrimas skirtas nustatyti, kokios dažniausios laikino sąmonės netekimo priežastys skubiosios pagalbos skyriuje, nagrinèti pacientų, atvykstančių su epilepsijos priepuoliais arba diagnozuota epilepsija, charakteristikas, įvertinti teikiamos apžiūros ir pagalbos lygị, atsižvelgiant ị tarptautines rekomendacijas.

Tiriamieji ir tyrimo metodai. Duomenys buvo rinkti skerspjūvio principu iš Vilniaus universiteto ligoninės Santaros klinikų duomenų bazès nuo $2016 \mathrm{~m}$. sausio $1 \mathrm{~d}$. iki gruodžio $31 \mathrm{~d}$. I tyrimą buvo ịtraukti visi minèto laikotarpio suaugę pacientai (iš vi so - 315 atvejų), kuriems buvo priskirta apalpimo ir kolapso (R55), epilepsijos (G40) ar kitu ir nepatikslintų traukulių (R56.8) diagnozè (koduota pagal Tarptautinę statistinę ligų ir sveikatos sutrikimų klasifikaciją, TLK-10-AM): arba kaip siuntimo (greitosios medicinos pagalbos), arba kaip galutinè skubiosios pagalbos skyriaus specialistų diagnozè. Duomenys analizuoti programomis Microsoft Excel v16.0 ir IBM SPSS Statistics v20, naudoti dvipusiai Fišerio ir Mann-Whitney U testai $(\mathrm{p}<0,05)$

Rezultatai. Kadangi siuntimo ir galutinès diagnozės dažnai nesutapo, analizès metu remtasi tik pastarosiomis. Daugumai pacientų, atvykusių i priẻmimo-skubiosios pagalbos skyrių dèl laikino sąmonès netekimo (vidutinis amžius $-53,5 \pm 20,8 \mathrm{~m}$.), buvo nustatytas alpimas ir kolapsas (134, 42,5 \%), 54 (17,1\%) - epilepsija, o $32(10,2 \%)$ - kiti ir nepatikslinti traukuliai (diagnozé, taikoma ir priepuoliui įvykus pirmą kartą gyvenime). Pacientų su diagnozuota epilepsija amžiaus vidurkis buvo 47,6 \pm 15,7 m. - reikšmingai mažesnis nei kitų diagnozių atvejais $(p=0,014)$. Kai buvo vertinti bet kokios kilmès epilepsijos priepuoliai, vyrai su atitinkamomis diagnozėmis i prièmimo-skubiosios pagalbos skyrių būdavo pristatomi dažniau (šansų santykis OR $=1,7$, $95 \%$; patikimumo intervalas $\mathrm{CI}=1,0-2,9, \mathrm{p}=0,042$ ). Laboratoriniai kraujo tyrimai buvo atliekami dažnai ir pacientams su ịvairiomis diagnozėmis, tačiau sergantieji epilepsija dažniau gaudavo kompiuterinès tomografijos (KT) tyrimą, dažniau būdavo hospitalizuojami ( $\mathrm{p}<0,001, \mathrm{p}=0,002$, atitinkamai). Tokiems pacientams rečiau būdavo atliekama elektrokardiograma ir nustatomi troponinų kiekiai kraujyje $(\mathrm{p}<0,001)$, nes šie testai dažniau taikomi pacientams su apalpimu ir kolapsu. Židininiai $(32,59,3 \%)$ ir metaboliniai su alkoholio vartojimu susije priepuoliai $(8,14,8 \%)$ buvo dažniausiai esant epilepsijai, o nežinomi ar nepatikslinti $(22,68,8 \%)$ ir generalizuoti $(6,18,8 \%)$ priepuoliai - stebint pirmą kartą vykusius priepuolius. Ambulatoriškai gydyti siųstiems epilepsijos pacientams alkoholio abstinencija $(16,44,4 \%)$ ir rekomendacijos, susijusios su kasdienybe, laisvalaikiu, darbu ir kt. $(13,36,1 \%)$, buvo dažniausios indikacijos, taip pat dažnai modifikuotas arba pradètas gydymas vaistais $(14,38,9 \%)$. Nehospitalizuotiems pacientams su priepuoliais, bet nediagnozuota epilepsija, dažniausiai nurodomos indikacijos buvo neurologo konsultacija, elektroencefalografija $(19,76,0 \%$ ir $11,44,0 \%$, atitinkamai) ir alkoholio abstinencija $(11,44,0 \%)$, tačiau gydymas beveik nebūdavo skirtas.

Išvados. Apalpimas ir kolapsas, epilepsija ir priepuoliai be diagnozuotos epilepsijos buvo dažniausios laikino sąmonès netekimo priežastys. Pacientai, kuriems diagnozuota epilepsija, buvo jaunesni nei kitais atvejais, o vertinant visas priepuolių priežastis - vyravo vyriška lytis. Pacientų ịvertinimas ir konsultavimas prièmimo-skubiosios pagalbos skyriuje dažniausiai atitiko tarptautines rekomendacijas, jei nepaisytume kai kurių skirtumų, susijusių su neurovizualiniais tyrimais, informacijos pacientams sklaida.

Raktažodžiai: laikinas sąmonės netekimas, epilepsija, epilepsijos priepuoliai, skubiosios pagalbos skyrius.

Gauta:

Priimta spaudai:

20180915 